\title{
The Role of Culture and Folk Art in School Library Programming
}

Lucy Santos Green

Associate Professor

University of South Carolina

lgreen2@mailbox.sc.edu

\section{Melissa P. Johnston}

Associate Professor

University of West Georgia

mjohnsto@westga.edu

\section{Introduction \& Research Purpose}

Exploring the practices of teacher librarians in other countries fosters new knowledge, contributing to global communities of practice. The need to equip today's youth with complex $21^{\text {st }}$ century skills has served as a catalyst for change in the traditional practices of school librarians all over the world. It is this necessary change that led to questions regarding school library practices at an international level and to the need to explore school librarianship on a global level. This research study explores ways program design grounded in cultural understanding, experiences, and ways of knowing the world, are applied by practicing school librarians in Brazil, Russia, and Belize.

\section{Literature Review}

Culturally responsive programming (CRP) is a pedagogical approach that "empowers students to maintain cultural integrity, while succeeding academically" (Ladson-Billings, 1995). Gay (2010) points out CRP acknowledges the strengths of students' diverse heritages, comprehensively using "cultural resources to teach knowledge, skills, values, and attitudes" (p. 34). Inclusion of personal culture is important because classroom culture is influenced by the explicit or implicit presence of several groups: students, teachers, school, and community. These spheres of influence impact interaction efforts between teachers and students, as well as amongst the students themselves (Johnston, 2013a).

Windschitl (2002) and Edelson et al. (1999) both emphasize the importance of drawing upon students' cultural background and previous knowledge as student interest is closely related to personal history. For example, learners who share personal experiences through storytelling demonstrate both linguistic and metacognitive growth (Cortazzi \& Jin, 2007; Nicholas, Rossiter \& Abbott, 2011). Maier and Fisher (2006) determined successful integration of digital storytelling in a middle school classroom (ages 11-13) was highly dependent on the ability of students to relate the story subjects to their own lives. Students who chose their digital story topics in yet another project, selected topics closely tied to their history and personal struggles (Smythe \& Neufeld, 2010). Green and Johnston (2015) found a close relationship between reading for pleasure and inclusion of cultural activities in Brazilian school library programming. They concluded that school administrators should avail themselves of school library professionals who can help promote lifelong reading for pleasure through cultural activities. 


\section{Methodology}

Institutional ethnography (IE) is a methodology that enables the researcher to connect issues across multiple (and unfamiliar) sites, uncovering how institutional factors shape practice in sometimes unrecognized ways (Campbell \& Gregor, 2004). Therefore, it served as a strong approach for investigating the practices of teacher librarians in different countries and contexts.

The IE researcher learns by focusing on actual people, their work, and the conditions of their work (Given, 2008), therefore this research was conducted using traditional ethnographic methods of participant observations, structured and semi-structured interviews, and textual analysis. The researchers visited 28 schools in Brazil, four in Russia, and 22 in Belize. Structured and semi-structured interviews were conducted with teacher librarians, teachers, and school administrators at each site. Interviews were recorded, but were also immediately translated and annotated by the researchers, which allowed interviewees to member-check all information collected, clarifying possible misinterpretations from translation (Lincoln \& Guba, 1985). Participant observation allows the researcher access to the participant's culture while still maintaining objectivity (Creswell, 2013). Utilizing an observation protocol adapted from Johnston (2013b), researchers recorded observations and verbal exchanges concerning school library policies, procedures, and practices. The researchers also used videos, photographs, and detailed field notes. The use of multiple data sources and continued member checks through follow up emails were used to triangulate data while reviewing material for authenticity and reliability (Denzin \& Lincoln, 2008).

The researchers utilized inductive qualitative content analysis to analyze interview transcripts, observation questionnaires, and field notes, culling emerging themes from the data (Glaser, 1965; Zhang \& Wildemuth, 2009). During this process, the researchers applied open codes to the notes and topic headings written in the text during reading to describe manifest and latent aspects of the content. The codes were then grouped according to similarity under higher order themes, and assigned themes using content- characteristic words taken from the professional literature (Hsieh \& Shannon, 2005). Themes are consistent phrases, expressions, or ideas common among the participants derived directly and inductively from the data (Creswell, 2013).

\section{Findings \& Discussion}

The themes that emerged from this research reflect common practices of school library programs throughout the world. The current presentation will focus on one of the themes culled from the data collected: The inclusion of cultural programming. This theme addresses how culturally responsive programming was implemented to promote reading for pleasure, support alignment with literacy development and instruction, and center library as a place of belonging for all school and community members. Findings included in this theme were the integration of folk art, folk costumes, storytelling, multicultural celebrations and partnerships, and theatrical presentations in order to empower students to maintain cultural integrity, while being supported for academic success. Examples include: 1. Russian school libraries implementation of units on folk stories spanning Eastern Europe, giving students the option of reframing stories through costume, dance, diorama, or original music composition (a song); 2. Belize school librarians hosting book clubs that focused on reading traditional folk tales; 3. Brazilian school libraries who partnered with local community organizations to sponsor visits by local storytellers specializing in African-Brazilian history.

\section{Conclusions}

The application of Culturally Responsive Programming by school library practitioners should address "dispositions, incorporation of multicultural curriculum content, equal access, and high expectations" 
(Brown-Jeffy and Cooper, 2011, p. 74). The findings of this study echo Brown-Jeffy and Copper (2011) in determining that excellence and equity in school library programming depends on the design and application of curriculum that "is inclusive of students' cultural experiences" (p. 73). As teacher librarians around the world adapt and evolve to meet the needs of the 21 st century, a worldwide perspective allows us to engage in partnerships that provide opportunities to learn from, share expertise with, and support one another, thus strengthening the practice of school librarianship throughout the world.

\section{References}

Brown-Jeffy, S. \& Cooper, J. E. (2011). Toward a Conceptual Framework of Culturally Relevant Pedagogy: an Overview of the Conceptual and Theoretical Literature. Teacher Education Quarterly, 38(1), 65-84. Retrieved from http://www.eric.ed.gov/PDFS/EJ914924.pdf

Campbell, M., \& Gregor, F. (2004). Mapping social relations: A primer in doing institutional ethnography. Aurora, ON: Garamond Press.

Cortazzi, M., \& Jin, L. (2007). Narrative learning, EAL and metacognitive development. Early Child Development and Care, 177, 645-660.

Denzin, N. K., \& Lincoln, Y. S. (2008). Strategies of qualitative inquiry (3rd ed.). Thousand Oaks, CA: Sage.

Creswell, J. W. (2013). Research design: Qualitative, quantitative, and mixed methods approaches (4th ed.). Thousand Oaks, CA: Sage.

Edelson, D., Gordin, D. \& Pea, R. (1999). Addressing the challenges of inquiry-based learning through technology and curriculum design. The Journal of the Learning Sciences, 8(3 \& 4), 391-450.

Gay, G. (2010). Culturally responsive teaching (2nd ed.). New York, NY: Teachers College Press.

Given, L. M. (Ed.). (2008). The SAGE encyclopedia of qualitative research methods. Thousand Oaks, CA: SAGE Publications, Inc.

Glaser, B. G. (1965). The constant comparative method of qualitative analysis. Social Problems, 12(4), 436-445.

Green, L. S. \& Johnston, M. P. (2015). Global perspectives: Exploring school-based Brazilian librarianship through institutional ethnography. School Libraries Worldwide, 21(1), 1-18.

Hsieh, H. F., \& Shannon, S.E. (2005). Three approaches to qualitative content analysis. Qualitative Health Research, 15(9), 1277-1288.

Johnston, M. P. (2013a). Investigating an international exchange of best practices: An institutional ethnography approach. In Proceedings of IASL 42nd Annual International Conference \& 17th International Forum on Research in School Librarianship, Bali, Indonesia.

Johnston, M. P. (2013b). Investigating an international exchange of best practices between German and American teacher librarians. School Libraries Worldwide, 19(1).

Ladson-Billings, Gloria (1995). Toward a theory of culturally relevant pedagogy. American Research Journal, 32(3) 465-491.

Lincoln, Y. S., \& Guba, E. G. (1985). Naturalistic inquiry. Beverly Hills, CA: Sage Publications.

Maier, R. \& Fisher, M. (2006). Strategies for digital storytelling via tabletop video: Building decision making skills in middle school students in marginalized communities. Journal of Educational Technology Systems, 35(2), 175-192.

Nicholas, B. J., Rossiter, M. J., \& Abbott, M. L. (2011). The power of story in the ESL classroom. The Canadian Modern Language Review, 67(2), 247-268.

Smythe, S., \& Neufeld, P. (2010). "Podcast time": Negotiating digital literacies and communities of learning in a middle years ELL classroom. Journal of Adolescent \& Adult Literacy, 53(6), 488-496. 
Windschitl, M. (2002). Framing constructivism in practice as the negotiation of dilemmas: An analysis of the conceptual, pedagogical, cultural, and political challenges facing teachers. Review of Educational Research, 72(2), 131-175.

\section{Biographies}

Lucy Santos Green is an Associate Professor at the University of South Carolina, where she teaches in the school of library and information science. Her research focuses on technology-enabled learning and instructional partnerships.

Melissa P. Johnston is an Associate Professor at the University of West Georgia, where she teaches graduate courses in the school library certification program. Her research focuses on the school librarian's leadership role in integrating technology. 